\title{
Catholic Modernity and the Italian Constitution
}

Thomassen, Bjørn; Forlenza, Rosario

Published in:

History Workshop Journal

DOI:

10.1093/hwj/dbv039

Publication date:

2016

Document Version

Peer reviewed version

Citation for published version (APA):

Thomassen, B., \& Forlenza, R. (2016). Catholic Modernity and the Italian Constitution. History Workshop Journal, 81(1), 231-251. https://doi.org/10.1093/hwj/dbv039

\section{General rights}

Copyright and moral rights for the publications made accessible in the public portal are retained by the authors and/or other copyright owners and it is a condition of accessing publications that users recognise and abide by the legal requirements associated with these rights.

- Users may download and print one copy of any publication from the public portal for the purpose of private study or research.

- You may not further distribute the material or use it for any profit-making activity or commercial gain.

- You may freely distribute the URL identifying the publication in the public portal.

Take down policy

If you believe that this document breaches copyright please contact rucforsk@kb.dk providing details, and we will remove access to the work immediately and investigate your claim. 


\title{
Catholic Modernity and the Italian Constitution
}

\author{
INTRODUCTION: CONSTITUTING POLITICAL MODERNITY
}

Constitutions are founding texts for modern political life. The grounding principles exposed serve as underpinning guidelines for political life, and in a most technical sense: who can decide what, when, where and how. But much more is at stake. A constitution not only stipulates single rules; it also gathers these rules in meaningful 'bundles', ensuring an overarching division of powers. If society is a body, then the Constitution forms the skeleton. Constitutions guarantee political legitimacy at the most basic level, telling citizens why they must obey. They justify and delimit power. Max Weber's famous definition of the modern state as that entity which holds monopoly of legitimate violence is surely reductionist, but it shows his keen understanding of the sociological dimension of law. By guaranteeing rights (as well as duties), constitutions also tell the citizens embraced and defined by the text how they can disagree, within the bounds of law.

Constitutions are legal texts first and foremost, and written in that juristic Enlightenment-inspired language which—despite differences—has come to assume a striking similarity across the globe. We can see that constitutions differ, but we understand the language they speak. Constitutions are therefore also, in a broader vein, key documents of political modernity. As such they often come to assume an importance far beyond their institutional role. They do not simply stipulate principles: they bring those principles into existence. They have an enormous degree of annunciative power: they create by declaring. What they say is. The principles and ideals they espouse are formulated in a language of eternity: the present tense operated ('The Federal Republic of Germany is...' or 'Italy is...') is not meant to indicate a shifting present, quite the contrary: it lifts itself beyond historical time. The present-ness reads as the eternal 
today — and as the eternal tomorrow. In fact, as etymology reminds us, the present is the here and now, but it is also that which is always before ('pre') being ('esse'). It is always already there: it 'simply' presents itself, ceremonially so. The gift-giving aspects of the word 'present' rhymes with the temporal dimension: something is literally brought into somebody's presence.

Constitutions are both written and signed by historical persons, physical bodies. But it is a peculiar form of authorship. The writing subject is hidden away; the third person neutral gives voice. Very quickly the message of the text assumes its own life, becoming perfectly readable without knowing the author. The Constitution is a gift circulating without the giver. The text gains in meaningfulness exactly in the absence of the author; the message it sends is absorbed as the intentionality evaporates into the general 'we'. In fact, constitutions, better than any other document, display all the features of that collective time-experience which Benedict Anderson recognised as lying at the heart of nationalism: progressive time, eternal time, secularized-sacred time, homogenous and 'empty', but brought together in an imagined community. Its newness is formulated with respect to principles and values that are posited beyond time and space. God is replaced by People, hence its modern-ness; yet it is still a cosmogony, and it carries tempo-spatial transcendence within it. It is also therefore that constitutions can become salient reference points for social collective bodies at the level of identity, as the American experience documents so well: they bind together a populace across time and beyond social divisions.

Put differently, the very notion of constitution harbours a double meaning: first, it concerns a written document and the rule of law emanating from $\mathrm{it}^{\mathrm{ii}}$; second, it refers to a constitutive act that precedes the establishment of a political regime, and constitutes a people as a political community. In the understanding of Thomas Paine, the American Constitution was not an act of government, but of a people constituting a government. iii 
The constitution belongs to the social body; it is, in a sense, the social body declaring its own existence, emanating from the will of the people. The constitution is not only the skeleton of a political society; it is also its heart. The way it bespeaks itself into existence therefore matters.

Following Derrida, constitutions may be analysed as 'performative utterances'. Words become symbols within a symbolic matrix. The constitution is a speech act, and as such its language has affects far beyond the dissemination of what is right and wrong, what is a duty and what is a right: language performs and produces effects. Language becomes part of a world-making. Of course, the effectiveness and meaningfulness of discourse is context-dependent: not anyone can say the same words and bring about an effect. We can only 'do things with words' iv if we are placed in the right position at the right moment. 'I pronounce you man and wife', spoken at the end of wedding ceremony, has meaning and affect only if certain conditions are in place. Meaning is not attached in an intractable or permanent way to a particular set of signs, marks or sounds; it is brought about in a specific context, which is sociologically and historically bound. In Signature Event Context Derrida famously argued that this context-dependence is a constitutive feature of all utterances; that all contexts are themselves contingent. There are, Derrida maintains, only contexts 'without any centre or absolute anchoring'. In fact, there is no 'con-text' that 'explains' the text: all we have are a series of texts which are themselves contingent. When we believe to establish a 'con-text' we are in fact engaged in writing yet another text.

We do not have to endorse all the epistemological consequences of Derrida's deconstructivist position to appreciate the point he makes, opening up 'grounding' texts such as constitutions or declarations of independences to a different kind of reading. Words do matter, and constitutions are indeed prime examples of political performativity, invested with an enormous load of symbolic power. From his more 
sociological perspective, Bourdieu insisted that the power of words is nothing but the delegated power of the speaker. ${ }^{\mathrm{vi}}$ We therefore have to consider the social conditions for the effectiveness of ritual discourse. Taking a cue from Arnold van Gennep, we may indeed take one step further and consider the writing of a constitution as belonging to a rite of passage ${ }^{\text {vii }}$ Constitutions mark a transition. To be more precise: constitutions are the final outcomes of a ritual passage, its closing act. Where the neophytes in a 'tribal setting' going through a ritual passage to manhood have their new status stamped onto their physical body, shown and marked in front of his society ritually recognizing his new identity as a man, ${ }^{\text {viii }}$ political societies have their new identity pinned down in the Constitution, closing the period of dramatic rupture and liminality that have typically preceded this phase of re-integration, as society is put back in place under the fold of a structuring order. ${ }^{\text {ix }}$ In fact, constitutions are often written in the aftermath of a war or otherwise dramatic upheaval, in the conscious attempt to reinstall order in a world of chaos and loss of legitimacy. Constitutions blaze the trail from anti-structure to structure. Constitutions are key 'closure events' in rites of passage as gone through by large-scale societies. Using Bourdieu's terminology, constitutions are prime examples of those 'rites of institution', e.g. consecration rites that bring about a change and simultaneously legitimise the very order they create. ${ }^{\mathrm{x}}$ To sum up: Constitutions are decisive performance acts within a period of transition that it helps to bring to a halt; in this process it shapes and moulds the new 'normality' which both annuls the previously existing and renders explicit, meaningful, legitimate, functional and cosmologically cohesive what is to come.

\section{CONSTITUTING ITALY AT THE END OF WORLD WAR II}

Ever since its official birth moment, 1 January 1948, the Italian Constitution has remained a touchstone in Italian politics and society. Studied in public schools from an early age, the document has also assumed an immense cultural-patriotic significance. 
Whenever a political debate gets heated, participants will, at one point or the other, invoke both the letter and the spirit of the Constitution to back up one's position or delegitimize that of the opponent. The 'founding fathers' of the Constitution are daily brought in play, in ways perhaps that they had not dared to envisage. Suggestions and attempts to rewrite the Constitution most often led to nothing, also because the Constitution itself (article 138) provided for an aggravated demanding procedure of revision. ${ }^{\mathrm{x}}$ The object of contention has always been part II of the Constitution (Organisation of the Republic), not Part I (Rights and Duties of Citizens, articles 13-54), and much less what concerns us here: the so-called Founding Principles (articles 1-12). Media tycoon and former Prime Minister Silvio Berlusconi (1994-1995, 2001-2006, 2008-2011) made several dubious utterances in his years as a politician, evidently thriving rather well within that Derridean space void of an anchoring centre, but one of the most provocative and unpopular ones was no doubt in February 2009, when he described the Italian Constitution as a 'Communist document' or, even worse, as a 'pro-Soviet document, made under the influence of a dictatorship' ${ }^{\text {xii }}$ In reality, with the Constitution Italy was exiting Mussolini's dictatorship and the document was drafted by Christian Democrats, Communists, Socialists, republicans, liberals and other small political forces jointed in the spirit of anti-Fascism. Today, it is with very mixed feelings that Italians hear of centre-left prime minister Matteo Renzi's attempt to alter parts of the Constitution toward a higher degree of 'governability'. In fact, scepticism is in the air anytime someone proposes to change the wording and the substance of the Constitution. Somehow, the Italian Constitution has gained an aura of sacrality. Touching any part of it, and especially the initial part which stipulates the founding principles of the Republic, easily appears as an attack on the precarious compromise it represents and defends, risking to throw into the wide open all the latent conflicts lurking beneath its protective

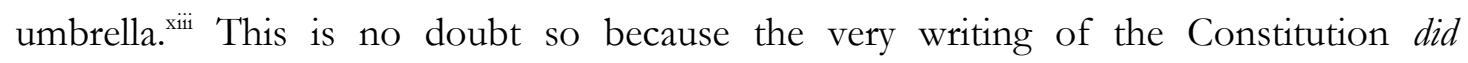


compromise the viewpoints of its founding fathers. It therefore fostered a compromise between the very composite segments of the Italian population that had voted the members of the Constituent Assembly into power on 2 June 1946- the very same day that gave birth to the Republic.

The aim of this article is simple: We want to assess the momentous turn in Italian politics that the writing of the Constitution signaled. Approaching the Italian constitution as a 'rite of passage', and as a 'performative utterance', there is one specific aspect of the Constitution that we would here like to focus on: the specific way in which the Italian citizen became symbolically 'coded' as a 'person' and not as an 'individual', inspired by Catholic principles. What interests us here is less the legal dimension of citizenship, and less the social consequences of the formulations eventually adopted; what we would like to discuss is the underlying semantics and the wider symbolic universe that came to underpin those rules, trying to provide Italy not only with an institutional skeleton, but also a heart and spirit.

Our argument therefore rests on the assumption that what is at stake in the writing of a constitution is indeed the grounding of political legitimacy in a philosophical anthropology. As famously argued by Eric Voegelin in his dispute with Hans Kelsen (probably the world's most famous constitutionalist ever), the political language adopted in constitutional writing must be understood as symbols of ideological self-interpretation. In The Authoritarian State (1936), no doubt one of his most important Vienna publications, Voegelin fundamentally charged Kelsen with ignoring the content of human life, thus disregarding the necessary sociological and anthropological foundations of any political theory; and of similarly ignoring the question of pre-constituted meaning. Relatedly, in his approach to the history of political thought, one of Voegelin's crucial methodological insights was that 'ideologies' had to be analysed as symbolizations of human experiences. ${ }^{\text {xiv }}$ 
Here it must be remembered that the Italian Constitution was written in a real 'empty space, ${ }^{\mathrm{xv}}$ with no foregone conclusions, in a historical figuration of quite radical contingency, which we have elsewhere conceptualized as a liminal moment. ${ }^{\text {xvi }}$ Liberal pre-Fascist constitutional traditions were potentially available, but evidently could not solve the challenges faced. The Constituent Assembly elaborated the final document under a cloud of uncertainty: what next? As such, its members were forced to focus on the (imagined) future more than on present aims and objectives-opening the ground for a virtuous and vital compromise across political, ideological and philosophical divides. ${ }^{\text {xvii }}$ Unlike Japan and (if to a lesser extent) West Germany, the Anglo-American allies left the constitutional process for the Italians to deal with. xviii The future was up for grabs.

Concretely, our aim is to analyze the Catholic contribution to the Italian Constitution. In this context we discuss what we have elsewhere tried to capture as the Catholic 'appropriation of modernity'. xix Scholars often insist that Christian Democracy, especially in its Catholic-Italian version, represented no real tradition of political thought, but was merely a means toward establishing strong ruling parties. ${ }^{\mathrm{xx}}$ This judgment might be motivated by the undeniable dullness of Christian Democratic politicians; but more likely it is explained by the fact that scholars never took Christian Democracy seriously as a political idea. ${ }^{\mathrm{xxi}}$ In Italy this perception was reinforced by revelations about Tangentopoli ('Bribesville', a metaphor for a huge corruption scandal discovered in the early 1990s). To be sure, the Cold War, American financial and political support, and the 'occupation' of the Italian state by Christian Democracy were important in ensuring its hold on power from the end of World War II until 1994. Yet, the role of ideas cannot be easily dismissed. At the end of the war, a reliable ideological body had to be distilled against the background of Fascism. From a Catholic perspective, this body had to appear as authentically universal without succumbing to Church dogma, yet present itself as 
particularly Italian-thus, Christian Democrats formulated a profusion of ideas conducive to the adaptation of Italian Catholicism to the standards of a modern democracy and a fairly advanced welfare state. Engaging Catholic contributions to the Constitution therefore means to engage a crucial chapter of Italian history and politics. We argue that Catholic thought and social philosophy had a direct impact on political life_-clearly visible in the drafting of the Constitution; this, in turn, indexes how Catholic ideas sought to interpret and give direction to the very idea of political modernity. The specific argument therefore pertains to a larger theoretical discussion concerning modernity and 'multiple modernities'.xxii

\section{FROM CAMALDOLI TO THE CONSTITUTION}

Catholic debates on the new constitutional architecture of post-Fascist Italy started while World War II was still on, and even before Mussolini's fall from power on 24-25 July 1943. From 18 to 23 July 1943, members of the Movimento Laureati ('Association of Catholic Graduates and Professionals') and exponents of the Istituto Cattolico di Attività Sociali ('Catholic Institute of Social Activities') drew up the so-called 'Code of Camaldoli', a work of social culture that consciously attempted to update the Code of Malines, the first attempt of formulating a Catholic social doctrine, produced in 1927 by the International Union of Social Studies in Malines (Belgium). Entitled For the Christian Community: Principles of the Social Order Drawn Up by a Group of Friends of Camaldoli, the document was published only in 1945 but circulated in the underground beforehand. The Code was heavily inspired by the philosophy of Thomas Aquinas and represented a summa of thought on society, economy and state organization in light of Catholic doctrine. It contained a consciously articulated Catholic proposal to rebuild a new social and political order at the end of the war. The model for an ideal society cherished by young Catholic intellectuals was inspired by Christianity, but it was also rooted in the 
concrete analysis of class dynamics, the existing social groups within Italy, and a concrete understanding of the its political and institutional life. What was needed, apart from the theoretical and spiritual input, was to 'ascertain how persons and groups could be concretely engaged in the social and political dynamic'.xiii

After an introduction on the 'premise on the spiritual foundation of the social life', the Code focused on State, Family, Education, Work, Production and Exchange, Economic Activity, and International Life. ${ }^{x i v}$ In a sense, the Code stipulated the framing of a government program. It affirmed the necessity of state intervention in the economy, consciously indicating a 'third way' beyond pure market capitalism and state socialism, half a century before the Giddens-Blair ticket. It also pleaded for a decentralized, almost federalist organization of the State, based on strong local autonomy. An essential characteristic was the identification of solidarity and social justice as primary aims of the State on par with safeguarding freedom.

Sergio Paronetto, probably the major contributor to the Code, advocated the need to concentrate upon the historical contingency. With great independence from Catholic social teaching, he believed that socio-economic issues must be measured and dealt with on their own inherent terms-albeit firmly grounded in a Christian conscience and a spirituality shaped by the 'ascetic of the man of action'. ${ }^{x x v}$ Paronetto refrained from direct engagement from party-political activities. However he cooperated with Alcide De Gaperi, who would became the first Catholic prime minister of Italy (1945-1954), in the elaboration of the 1943 Reconstructive Ideas of Christian Democracy - the document that lay down the party's organizational-intellectual foundations. It is also for this reason that the Camaldoli Code gave momentum to Christian Democratic dynamic reformism as it came to effect in the late 1940s and early 1950s, and supported Catholic participation to the writing of the Constitution. ${ }^{\text {xxi }}$ 
Catholic debate on the new Constitution continued with even more energy in the months following the end of the war. ${ }^{\text {xxvii }}$ For example, the nineteenth 'social week of Italian Catholics', held in Florence in October 1945, dealt directly with 'Constitution and Constituent Assembly,. xxviii Quite crucially, a group of left-leaning Christian Democratic thinkers and politicians became involved in the drafting of the Constitution, sitting on the board appointed to draw up the new charter. Giuseppe Dossetti (a young Canon Law professor from the Catholic University in Milan) and Giorgio La Pira (one of the 'Camaldoli's friends', later to become mayor of Florence) were the most prominent figures in this group of intellectuals, often called not without sarcasm the professorini (young, fledgling professors), or also the dossettiani. The movement Civitas Humana (founded in 1946) and the journal Cronache Sociali (1947-1951) served as a platform to articulate the group's ideals and plans for the institutional, social, and economic design of postwar Italy. ${ }^{\text {xix }}$

Dossetti had fought in the Resistance and served in the Committee of National Liberation. ${ }^{\mathrm{xx}}$ In 1945 he was made vice-secretary of the Christian Democracy and tried to open the party to pacifist and even socialist ideas. He had been deeply impressed by the Labour party's 1945 election victory in Britain. ${ }^{x x i} \mathrm{He}$ and his circle of friends and collaborators became enthusiastic admirers of Stanford Cripps's 'Christian socialism' and engaged with John Maynard Keynes and William Henry Beveridge by mistakenly taking them for Labour politicians. ${ }^{\text {xxxii }}$ La Pira drew extensively on Keynes, Lord Beveridge, The Economist, and Jesus Christ, collectively seen as the ultimate economic and spiritual points of reference. In 1950 he published two articles in which he explained the relevance of Keynes for post-war Italy, arguing that his economic policy was in tune with the Gospels. ${ }^{\text {xxxiii }}$

Formed in the 1930s, in the intellectual climate of the Università Cattolica, Milan—at that time engaged in a harsh controversy with the Idealist conception of the Ethical State 
developed by the Fascist premier philosopher Giovanni Gentile-the professorini were also fascinated by French legal-social currents of thinking, including authors such as Léon Duguit, Maurice Hauriou and Georges Gurvitch, not to mention the 'institutional' ideas of the Italian constitutionalist, Santi Romano, who had always shown a special concern with social reality on which legislation should be based. ${ }^{\text {xxiv }}$ During the 1930s Dossetti and many other future dossettiani had flirted with Fascism, which they at the time considered to be the best available model for the preservation of Catholic values. Yet visà-vis the increasing association of Fascism with Nazism and its racial policies, Dossetti drifted away from traditional Catholic intransigence and 'romanità', still advocated in 1940 by the founder of the Cattolica Agostino Gemelli. . $^{x x v}$ Strongly influenced by the experience of war, Dossetti, as other Catholics around him, began searching for a Catholic response to the challenge of modern mass politics. His aim was to bring the Church into alliance with the modern world. Dossetti saw that it was necessary to take a stance, and become directly involved in active politics, first by fighting in the Resistance alongside communists and socialists, and later by active militancy in the Christian Democracy. At the intellectual level, the search for a Catholic response to the challenges of modern society, meant bringing into the new democratic culture of postwar Italy the thoughts the dossettiani had avidly read and carefully reflected upon in the 1930s-those of a number of European Catholic thinkers who had led the way in embracing crucial aspects of modernity and human rights as indispensable to a proper Catholic view of the world.

This is important to understand. At the political-institutional level the interwar years were disastrous for political Catholicism, in Italy as well as in Germany and in other European countries.xxxvi However, Catholic thought had not come to a standstill, developing in fact as a meditation on the failures and setbacks of the interwar period. At 
the end of the war, Italian Catholic politicians found inspiration from across the Alps. A central figure in the debates remained the French philosopher Jacques Maritain.

\section{MARITAIN: THE CATHOLIC GROUNDING OF}

\section{THE DEMOCRATIC ORDER IN THE HUMAN 'PERSON'}

Maritain had been close to the quasi-fascist Action Française in the 1920s. He had abandoned the movement when it was condemned by the Vatican in $1926 .^{\text {xxxvii }}$ Working within a neo-Thomist philosophical framework, in the 1930s he started to embrace human rights and modern democracy. In particular, his 1936 study Humanisme Intégrale and his 1942 pamphlet Christianisme et démocratie — which was dropped by Allies plans over Europe in 1943 - had constituted a decisive endorsement of the ultimately Christian nature of democracy.

It would be wrong to reduce this development to the French context. What slowly took shape during the 1930s happened in a transnational dialogue. As discussed by Samuel Moyn, also with reference to the work of James Chapell, the idea of the human person as the bearer of 'constitutional dignity' can be traced back to the Irish constitution of 1937. A hugely influential document here was the 1937 encyclical Divini redemptoris, which fundamentally asserted the dignity of the human person. The encyclical was as a direct response to the secular narrative of 'rights' and dignity bestowed upon the 'depersonalized individual' running from the French Revolution, and taken to extremes by the Communist regimes. Divini redemptoris is in fact a scathing attack on Communism by Pius XI. ${ }^{\text {xxxviii }}$

However, in the Italian context there is no doubt that French developments were of primary importance, and Maritain's ideas were the ones with the most direct influence. Central to Maritain's theory and definition of democracy was the concept of the 'person' and its opposition to the 'individual'. The 'person' has a spiritual and transcendent 
nature, irreducible to biology, and a concern for the good of all. It flourishes only within community and in relation with God—and, through God, with the good of all.

Maritain's writing influenced the emerging philosophy of 'communitarian personalism', and for a while Maritain acted as a mentor to its leading proponent Emmanuel Mounier. ${ }^{\text {xxxix }}$ During the 1930s Mounier and the group around the journal Esprit condemned both Communism and liberal individualism as forms of materialism. Liberal individualism, in particular, was held responsible for what Mounier disdained as 'le desordre établi', his designation for the corrupt parliamentary politics of the French Third Republic and for a political culture associated with the heritage of the French revolution; as he put it, 'on the altar of this sad world, there is but one god, smiling and hideous: the Bourgeois' ${ }^{\mathrm{xl}}$ As an alternative to the materialist twins of liberalism and Communism, Mounier insisted that the 'person', as opposed to the isolated 'individual', always realized him-herself in a community, while retaining a spiritual dimension that could never be absorbed into the politics of this world. At the practical level, Mounier and the personalists endorsed a society with a vigorous group life (not unlike the English pluralists), and characterized by the decentralization of the decision-making process to the grassroots or to communities with a human dimension. Mounier's concrete proposals were perhaps harmless. However, his rhetoric and expectations were revolutionary and hotly anti-liberal. Thus, he could briefly see room for the personalists in the Vichy regime during the war, and in Communism and Soviet Marxism after the war. ${ }^{\text {xli }}$

Maritain's philosophy had effects outside intellectual circles. Maritain played a key role in drafting the United Nation Declaration of Human Rights. Charles De Gaulle made him French ambassador to the Vatican after the war, from 1945 to 1948-a timeframe that coincided with the birth of Italian democracy and the emergence of Catholics as the country's new ruling class. Maritain played a crucial role in the Council Vatican II, together with John Courtney Murray and other lay intellectuals, and he was 
presented by Pope Paul VI with the 'Message to the Philosophers' at the closing of the Council. ${ }^{\text {lii }}$

Both Maritain and Mounier were in fact not necessarily in favor of founding explicitly Christian parties; rather, as Maritain repeated time and again, Christianity should be something like the 'yeast' of political life, making the liberation from pagan Fascism the first step to a new political cultural based on moral and, to some degree, religious argument. ${ }^{\text {xiii }}$ 'The question', Maritain wrote, 'does not deal ... with Christianity as a religious creed and road to eternal life, but rather with Christianity as leaven in the social and political life of nations and as bearer of the temporal hope of mankind ... as historical energy at work in the world'. xliv In 1934, intervening in a fracas between Mounier and Catholic philosopher Paul Archambault, Maritain insisted that the new Christianity could not be equated with a party program, being 'of a freer and more elevated order, which on the contrary seeks to renew the very manner of posing the problem'. Integral humanism 'could not be reduced to any of the operative ideologies in the political formation due to the nineteenth century and still extant'. ${ }^{x l v}$

Even more harshly—given his view on man, God and the world-Mounier, who had next to nothing to do with the drafting of the UNDHR, could not accept Christian Democracy; in fact he disliked Christian Democracy as a party project both in France, in the 1930s, and in the post-WWII era. Elections, party politics, and coalition governments—he thought—meant compromise and consequently corruption. His 'democratic' credential should not be overstated; actually his anti-liberalism sometimes bordered on anti-democratism. ${ }^{\text {xlvi }}$ In this as on a whole range of issues, he characteristically adopted ambivalent positions. He strongly affirmed the existence of transcended truth, but refused to grant absolute validity to any particular human expression of that truth. Thus Mounier shared with his mentor, Charles Peguy, the desire to incarnate the spiritual in the temporal; he also believed, like the Christian Democrats, 
in 'engagement'. Yet Mounier also spoke warningly of the 'temptation to political action', and wrote in one of his essays in the early years of Esprit: 'Is not any action condemned to inefficacy to the extent that it will be pure, impure to the extent that it will be efficacious?? ${ }^{\text {xlvii }}$ He was caught firmly on the horns of this dilemma throughout his political career as editor of Esprit. His conviction that Christians must be in but not of the world forced him to walk his theological-philosophical tightrope publicly. He was strongly anti-bourgeois but found himself cooperating with bourgeois politicians during every major crisis of the thirties, from the Spanish Civil War to the Munich crisis and beyond. He consistently criticized the Christian Democrats as too clerical and confessional, yet his own faith keep him from an outright commitment to the Popular Front, which had to be content with a fraternal salute in 1936. His antagonist Archambault accused him of imprecision, negation of capitalism tout court and doctrinal incoherence. For Mounier, then and later, the Christian Democrats were compromised by the liberal established disorder of the Third and Fourth Republics. He was consistently severe with regard to 'Christian Democratism', its inadequacies and its dishonest compromises. The question is: can one make a temporal commitment, especially one to radical anti-capitalism, without being involved in the established disorder?

\section{FRENCH CATHOLIC PHILOSOPHY GOES TO ITALY}

Without ridding itself of all of its open-ended questions and unresolved tensions, the thought of Maritain and Mounier came to constitute an important reference point for Christian Democrats in Europe and in Italy-including De Gasperi and the professorini. They would adopt the language of personalism as theirs as they became involved in the constitutional process. ${ }^{\text {lviii }}$ 
Following closely their French inspirers, the professorini criticized individualistic liberalism and saw the person as deeply embedded in a moral community. They saw their role and their analytical-moral effort within the larger picture of political modernity and what had gone wrong within this historical experience. They were driven by the idea of 'transcending the principles of 1789', as La Pira once put it. ${ }^{\text {xlix }}$ Or, as La Pira put it commenting on the Constitution a few weeks after it took effect, 'the human personality unfolds through organic belonging to the successive social communities in which it is contained and via which it steadily develops and perfects itself. ${ }^{1}$

La Pira was one of the experts on the principles of civil relations sitting on the board appointed to draw up the Constitution. Harking back to Hippolyte Taine, he explicitly stated that Rousseau's 'individualistic' principles must be revised in a return to an 'organic' universe. La Pira quoted Mounier and his Déclarations des droits des personnes et des communautés, which was written in 1941 and debated at the height of the Resistance in the pages of Esprit under the questioning title: 'Should We Rewrite the Bill of Human Rights? ${ }^{\text {li }}$

The professorini were aiming at an Italian version of a labour-based 'integral' democracy based on a holistic vision of the human person which could realize a Christian-inspired solidarity throughout Italian society and its institutional ramifications. Democracy could not have the 'empty' individual as the basic building block. Likewise, the economic order, based on market mechanisms, could not be justified with reference to purely economic principles, void of values. The economy had to be founded on the person; and the ultimate goal of economic development would always have to be referred back to the person and his or her fulfilment in a meaningful community (hence the slogan, 'First the person, then the market'). Throughout the post-war period, this idea would not be easy to implement within a wider socio-economic context of 
advancing capitalism and a slowly unfolding consumerism based on the American way of life, exploding with the 'economic miracle' from the mid-1950s. lii

There were profound disagreements between Dossetti (and his group) and De Gasperi. ${ }^{\text {liii }}$ The dossettiani wanted a sharper distinction between 'Catholic' and 'political' action—or, as Maritain would have said, between the 'temporal' and the 'spiritual'. The party, they believed, must operate not only as anti-Communist force-a generic publicopinion movement gathering consensus-but also as a centre of cultural elaboration and

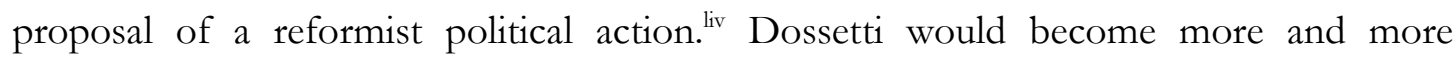
pessimistic about the possibility of Christian Democratic reformism. He was deeply dissatisfied with De Gasperi's government line which he openly criticized for lacking a serious social program. He was appalled by Italy's NATO accession and by the government's aggressive attitude towards the East. ${ }^{\text {lv }}$ In 1951 he chose to dissolve his faction in the party and retired to monastic life_only to return for a while in 1956, when he ran unsuccessfully for mayor in the Communist stronghold Bologna. ${ }^{\text {lvi }}$ Dossetti lost the belief that politics could be reformed from within. He became increasingly convinced that Italian politics could be reformed only on the condition that the Church be reformed so that it could regain its leading role. This conviction pushed him to play an important role in the Second Vatican Council.

\section{THE PROFESSORINI AND THE CONSTITUTION: CATHOLICISM AT WORK}

Implementing Catholic philosophy in real life was never bound to be an easy task. But as concerns the preparation and writing of the Constitution, the enterprise was largely successful. Let us briefly sum-up where and how.

For a start, the professorini and the Left of the DC managed to have their version of the first article of Constitution passed: the 'personalist' wording 'Italy is a democratic Republic founded upon work'-elaborated and proposed by Amintore Fanfani, another 
of the young professorini-prevailed over 'Italy is a democratic republic of workers' proposed by the Communist leader Palmiro Togliatti and a number of Socialists. ${ }^{\text {lvi }}$ The difference may seem minimal at a first glance, but it steered from the very outset the wording of the entire document away from a Socialist worldview.

Another expression in article 2-which makes a strong allusion to the rights of man— can be traced to Catholic viewpoint and social philosophy, namely: 'The Republic recognizes and guarantees the inalienable rights of man, both as an individual and in the social orders wherein he develops his personality. The Republic demands the fulfilment of the binding duties of political, economic, and social solidarity'.

The rights of man (and woman, we should now add) are legally proclaimed to be inviolable, but they are not suggested as 'sacred' and least of all 'natural'. The professorini were not at all proposing a return to pre-modern legal thinking: they were applying Christian philosophy within the parameters of the modern episteme. As a matter of fact, the dossettiani agreed with the other founding fathers to exclude meta-positive rights. ${ }^{\text {liii }}$ Interpreters of the Italian Constitution cannot escape the often neglected fact that Part I of the Constitution recites the 'Rights and Duties of Citizens', much more similar to the Weimar Constitution of 11 August 1919 did (Grundrechte und Grundpflichten der Deutschen) than to the French Declaration of 26 August 1789, entitled 'Declaration of the Rights of Man and of Citizens'. And it is remarkably clear how the 'rights' are immediately related to the social level, and to the duties involved in the bringing about of social solidarity. Using an anachronistic language, the wording is Communitarian rather than Liberal.

Article 3 in turn stated (states!) that 'It is the Republic's duty to remove obstacles of an economic and social order physically constricting the freedom and equality of citizens and thus impeding the full development of the human person'. The conclusive words of article 3-'and the effective participation of all workers in the political and 
social organization of the country'-confirmed the dossettiani's will to collaborate with socialists and communists in order to steer away from liberal individualism.

As should be clear from now, the term 'person' implies a totally different value from that of 'individual' as employed in liberal thought penetrating most democratic constitutions. And it is this worldview that emanates from the core, from the founding principles that hold up the edifice.

\section{FREEDOM AND RESPONSIBILITY: THE LETTER AND}

\section{THE SPIRIT OF THE CONSTITUTION}

Thanks to the effort of Dossetti-and certainly also to his will and skills to develop a dialogue with socialists and communists - the Constitution enshrined not only the primacy of the human person as a part of a social union (that is also a spiritual union), but also the principle of freedom as a responsibility. The Catholic view of freedom was alternative, if not the opposite, to the idea of freedom elaborated by most currents of modern Constitutionalism. Freedom could only be accepted as the positive freedom to uphold the common good. In close affinity with Togliatti and the communists, the very young Dossetti-follower Aldo Moro declared-in a debate of the Constituent Assembly of 2 October 1946 (at the first subcommittee for the preparatory text of the Constitution) - that 'liberty in a democratic system is one that aims not to permit individual free will to be attained, but the full expression of a person's values, as well as positive collaboration by individuals to achieve the common good' lix The debate concerned an article for the Constitution proposed by La Pira-with the explicit aim of 'endowing liberty with a different meaning than the one underlying the 1789 Declaration'-which stated: 
The liberties guaranteed by this Constitution must be implemented to perfect the human person, in tune with the demands of social solidarity and toward the improvement of democracy by means of an increasingly active and conscious participation of all to the common good. Hence liberty is the foundation of responsibility (1 October 1946). ${ }^{\mathrm{lx}}$

This article, however, was not included in the final draft of the Constitution, despite the strong defence of Moro and Dossetti. However, even when unsuccessful, it is evident that the activism of Dossetti and the professorini hugely influenced the discussions held by the committee for the preparatory text for the Constitution. There was much debate, for instance, over whether the right to 'resistance' should be included in the text of the Constitution. The draft of the Constitution included indeed an article that read, 'the individual and collective resistance to oppression is a right and a duty of the citizen when the public powers violate the rights and fundamental liberties guaranteed by the Constitution'. This proposal followed a suggestion by Dossetti, and met with sharp opposition. ${ }^{\text {xi }}$ Over the course of the debate, the view that it was impossible to legally regulate something that, by its nature, was removed from the sphere of positive law prevailed, and the article was not approved. ${ }^{\text {lii }}$

Liberty and equality, far from being tools for identifying rival ideologies, are mutually reconciled in light of the 'full human person's development' enshrined in Article 3, which is made the cutting edge of constitutional principles. Civil, political, social and economic rights are accordingly recognised and granted. Rights of the individual are granted within communities such as families, schools, unions, parties, churches. Social and political pluralism becomes part of the constitutional landscape, grounded in what Mounier had talked about as a 'communitarian personalism'.

The pluralistic philosophy expressed here shines through in other parts of the 
document. For example, the second part of the Constitution, concerning the Republic's institutional framework, articulates public power both as shared among diverse institutions at the central level (parliament, government, president of the Republic, referendum, judiciary and Constitutional court), and among the State and local authorities, including regions, provinces and municipalities. This articulation is more sophisticated than Montesquieu's separation of powers, reflecting not only the need for granting citizens liberties, but also an essentially pluralistic view of democracy.

\section{CONCLUSION AND FURTHER PERSPECTIVES}

Our initial conclusion can be easily stated: The wordings of the Constitution discussed above represented small but significant results of a battle over values and visions of modernity won by the dossettiani. It was certainly a symbolic victory for the professorini, and with a lasting effect. The professorini had sought and contributed to build a post-liberal democracy, with distinct spiritual foundations. Moreover, the writing of the Constitution was the first political-cultural operation led by Catholic lay intellectuals and politicians without support from the Vatican. Christian Democracy achieved what political Catholicism had until then only been dreaming of: to regain a leading role in the modern world.

The wider perspectives to infer from this cannot here be fully elaborated in any detail, but let us at least sketch two dimensions involved that may prompt further theoretical reflection.

First, the Italian narrative is evidently not only an Italian story. The centrality of the 'person', a 'social' view of the economy, the defense of non-statal entities, from the family to the Church, and the valorization of forms of organization which were both political (parties) and corporative (trade unions): these were principles introduced, via Christian Democracy, not only in the Italian Constitution but also in European 'core' 
countries, France and West Germany. ${ }^{\text {liii }}$ This amply testifies that the received wisdom saying that Christian Democracy should not be taken very seriously as an autonomous political philosophy with real-world agency, simply does not stand up to scrutiny.

The Catholic imprint on the Constitution happened precisely as Catholics, through Christian Democracy, was becoming the dominant political force of the new republican Italy, and central actors in the process of building a modern mass democracy and a welfare state. Christian Democracy was in post-World War II Italy, as in many other European countries, the central forum for institutionalizing Catholic modernity-a momentous turn in Italian and European history that in retrospect is easy to miss. And in this vein let us simply remark the fact that this very same philosophical luggage had quite some influence on another group of founding fathers, namely those of the European community. ${ }^{\text {lviv }}$ Granted the increasingly heated discussions over Europe's founding values, and the deepening crisis of European integration, this perhaps deserves slightly more attention than what is currently the case.

Second, the Christian Democratic political thought epitomized in the writings and reflections of Dossetti and the professorini, was instrumental towards a shift of attitude that took place in the post-World War II period, where the Church, and Catholicism writ large, came to endorse 'modernity', or perhaps better, became a 'partner' of modernity. However this shift of orientation did not simply mean to accept and embrace modernity in its current shape. Nor did it mean, as implied by Paolo Pombeni, and as uncritically carried forward in the analysis offered by Jan-Werner Müller, to simply put forward liberal values once again, couched in a different vocabulary, with only cosmetic reference to a set of different ideas ${ }^{\mathrm{lvv}}$ : it meant, on the contrary, to develop and re-substantiate the modern call to freedom from within a classical and Christian tradition, opening the way for a 'integral' or 'organic' or also 'evangelical' or 'spiritual' post-liberal democracy. Such wording may sound vague and inherently open to interpretation, and questions certainly 
abound concerning its political realization. But may not the same be said about liberal formulas? We are not here simply dealing with a thinly veiled liberalism, mere jargon which did not alter a quintessential liberal substance re-emerging triumphantly after the 'parenthesis' of Fascism; we are dealing indeed with an alternative vision and political model, one that developed as a reflection on the misadventures of Fascism and as a critique of classical liberalism. Dossetti hated liberalism; in a way, liberalism represented the most serious of historical enemies to a healthy social and political order, as he explained in an emblematic letter he as partisan commander sent to the priests of the Appenines in March 1945. ${ }^{\text {lxi }}$

It is only within this political-cum-epistemological horizon that we can understand the letter and spirit of the Constitution. Christian-Catholic philosophy was no mere cosmetics, nor did it simply mark a transition towards the post-war liberal order. Quite the contrary: the Constitution closed the liminal period and in van Gennep's original terminology, marked the 're-aggregation', the constitution of a new, different order. It thus symbolized the successful closure of a double transition: from Monarchy to Republic and from Fascism to Democracy. It marked a new beginning, which was based on the historical compromise between Catholics, Social-Communists and other forces that had fought against Fascism—that is, it was based in the experience of the period of transition, 1943-1945, and the anti-Fascist struggle. The 'transition' unfolded within the realm of empirical history; Christian Democracy/political Catholicism brought it to an end. Or, to put it even more simply: Christian Democracy is not an ideology of transition', as Jan-Werner Müller has asserted, ${ }^{\text {lxvii }}$ but an answer to transition. 


\section{NOTES AND REFERENCES}

i Benedict Anderson, Imagined Communities: Reflections on the Origins and Spread of Nationalism, London and New York, 1991.

ii Hannah Arendt, On Revolution, London, 1963, pp. 142-45.

iii On this see also Harald Wydra, Communism and the Emergence of Democracy, Cambridge, UK, 2007, p. 15.

iv John L. Austin, How to Do Things with Words: The William James Lectures Delivered at Harvard University in 1965, Cambridge, Mass., 1967.

v Jacques Derrida, 'Signature Event Context' (1971), in Limited Inc., transl. Samuel Weber and Jeffrey Mehlman, Evanston, 1988, pp. 1-23: p. 12.

vi Pierre Bourdieu, Language and Symbolic Power, ed. John B. Thompson, transl. Gino Raymond and Matthew Adamson, Cambridge and Malden, Mass., 1992, p. 107.

vii Arnold Van Gennep, The Rites of Passage (1907), transl. Monika B. Vizedom and Gabrielle L. Cafee, Chicago, 1960.

viii Victor Turner, The Ritual Process: Structure and Anti-Structure, Chicago, 1969.

ix On liminality see Bjørn Thomassen, Liminality and the Modern: Living Through the In-Between, Farnham, 2014; see also Agnes Horvath, Bjørn Thomassen and Harald Wydra (eds), Breaking Boundaries: Varieties of Liminality, New York and Oxford, 2015. 
× Bourdieu, Language, p. 117.

xi Laws amending the Constitution are adopted by each of the two chambers (Senate and Chamber of Deputies) twice within no less than three months and need the approval of a majority of the members of each chamber in the second voting. They may then, upon a series of conditions, be submitted to popular referendum.

xii 'Berlusconi: "Costituzione ideologizzata”, Corriere della Sera, 7 February 2009. In 2003 Berlusconi had said that the Constitution was 'Soviet inspired'; 'Berlusconi: "La Costituzione è di ispirazione sovietica", la Repubblica, 12 April 2003.

xiii Three parliamentary commissions-convened in 1983-1985, 1992-1994, and 1997-1998 with the task of preparing major revisions of the 1948 text—were unsuccessful as political consensus was always missing in the end. The 'Great Reform' proposed by the centre-right government led by Berlusconi, which envisaged a strengthening of the power of Cabinet and prime minister, was passed by Parliament in 2005 but firmly rejected by voters in a nationwide referendum in 2006. Thus since 1948 the Constitution has remained substantially unchanged, except for the 2001 reform implemented by a centre-left coalition government, which is about decentralization and power relations between state and local entities.

xiv Eric Voegelin, Collected Works, vol. 4, The Authoritarian State: an Essay on the Problem of the Austrian State (1936), ed. Gilbert Weiss, Columbia, Mo., 1999. On the Voegelin-Kelsen dispute see Bjørn Thomassen, 'Debating Modernity as Secular Religion: Hans Kelsen’s Futile Exchange with Eric Voegelin', History and Theory 53:3, 2014, pp. 435-50.

xv The reference here is to political theorist Claude Lefort's concept of 'empty space of power' as constitutive of modern democracy; Claude Lefort, Essais sur politique XIXe-XXe siècles, Paris, 1986, p. 28. 
xvi Rosario Forlenza, 'Bewilderment and Re-composition: September 8, 1943 and the Liminal Origins of Italian Democracy' International Political Anthropology 4:2, 2011, pp. 133-57; Bjørn Thomassen, 'Notes Towards an Anthropology of Political Revolutions', Comparative Studies in Society and History, 54:2, 2012, pp. 679-706.

xvii Time and again, scholars and observers have defined the 1948 chart as the result of a 'constitutional compromise'; see Paolo Pombeni, La Costituente, Il Mulino, 1995, pp. 103-43.

xviii Cesare Pinelli, 'The 1948 Italian Constitution and the 2006 Referendum', European Constitutional Law Review, 2:3, 2006, pp. 329-40 (here pp. 330-31).

xix Rosario Forlenza and Bjørn Thomassen, Italian Modernities: Competing Narratives of Nationhood, New York, 2016 (forthcoming); see also Bjørn Thomassen and Rosario Forlenza, 'Christianity and Political Thought: Augusto Del Noce and the Ideology of Christian Democracy in Post-War Italy', Journal of Political Ideologies, forthcoming.

${ }^{x x}$ Christian Democrats were reportedly unable to elaborate an 'original' political theory: 'the true tradition of Christian democratic thought is found less in classic texts by a few keys authors, and more in the constant debates resulting from its being a political movement'; Mario Caciagli, 'Christian Democracy', in Terence Ball and Richard Bellamy (eds), The Cambridge History of Twentieth Century Political Thought, Cambridge, UK, 2003, pp. 165-80: 166. The tendency to reduce Christian Democracy to a useful electoral strategy—or a 'bargain of ideas' which filled the void in a historical moment marked by the vacuum created by the collapse of Fascism-is problematically present throughout the analysis offered by Müller; see for instance Müller, Contesting Democracy, p. 138; idem, 'The Paradoxes', p. 89, where Christian Democracy is reduced to 'pragmatism, power politics, and... the plundering the state'. 
xxi Analysis has focused on the twentieth-century conflict among secular ideologies (Fascism, Communism, Liberalism); Karl D. Bracher, The Age of Ideologies: A History of Political Thought in the Twentieth Century, transl. Ewald Osers (London, 1984); Eric J. Hobsbawn, Age of Extremes: The Short Twentieth Century, 1914-1991, New York, 1994; Mark Mazower, Dark Continent: Europe's Twentieth Century, New York, 1999; Toni Judt, Postwar: A History of Europe since 1945, New York, 2005. For analysis focused on Catholic ideas see Jan-Werner Müller, Contesting Democracy: Political Ideas in Twentieth-Century Europe, New Haven and London, 2011; idem, 'Towards a New History of Christian Democracy', Journal of Political Ideology 18:2, 2013, pp. 243-55; Paolo Pombeni, 'The Ideology of Christian Democracy', Journal of Political Ideologies 5:3, 2000, pp. 289-300.

xxii Sh'muel N. Eisenstadt, 'Multiple Modernities', Daedalus 129:1, 2000, pp. 1-29; on modernity/modernities as a historical problem see 'Roundtable: Historians and the Question of Modernity', American Historical Review 116:3, 2011, pp. 577-751.

xxiii Antonio Parisella, 'Christian Movements and Parties of the Left in Italy, 1938-1958', in GerdRainer Horn and Emmanuel Gerard (eds), Left Catholicism, 1943-1955: Catholic and Society in Western Europe at the Point of Liberation, Leuven, 2001, pp. 142-73: pp. 145-46.

xxiv Per la comunità Cristiana. Principi dell'ordinamento sociale a cura di un gruppo di studiosi amici di Camaldoli, Rome, 1945.

xxv This is the title of a posthumous collection of his writing; Sergio Paronetto, Ascetica dell'nomo d'azione, Rome, 1948. Paronetto died prematurely in 1945. On Paronetto's intellectual and personal biography see Giovanni Farese and Stefano Baietti (eds), Sergio Paronetto e il formarsi della costiturione economica italiana, Soverian Mannelli, 2012.

xxvi Giorgio Campanini, 'Dal Codice di Camaldoli alla Costituzione: I cattolici e la rinascita della democrazia', Aggiornamenti Sociali 57:5, 2006, pp. 399-410; see also 'Il Codice di Camaldoli e la riemergenza del cattolicesimo politico', Civitas 10: 1-2, 2013, special issue. Although it is not our 
focus here, it should of course be said the governments lead by Christian Democracy launched several reforms in the first years of the Republic which followed from Camaldoli's ideological core: the housing development scheme (Fanfani-law); the introduction of 'progressive' taxation by minister of Finance Ezio Vanoni (one of the Camaldoli's friends); the Agrarian Reform and the Cassa per il Mezrogiomo (the public effort to promote investments in the South); the creation of public agencies in the economy; see Rosario Forlenza, 'A Party for the Mezzogiorno: The Christian Democratic Party, Agrarian Reform and the Government of Italy', Contemporary European History 19:4, 2010, pp. 331-49.

xxvii Renato Moro, 'I movimenti intellettuali cattolici', in Roberto Ruffilli (ed.), Cultura politica e partiti nell'età della Costitutente, vol. I, Bologna, 1979, pp. 159-261; Mario Casella, Cattolici e Costituente: orientamento e iniziative del cattolicesimo organizzato, 1945-1947, Naples, 1987; Paolo Pombeni, 'Il contributo dei cattolici alla Costituente', in Silvano Labriola (ed.), Valori e principi del regime repubblicano, I: Sovranità e democraz̨ia, Rome-Bari, 2006, pp. 37-80.

xxviii Costiturione e Costituente: La XIX Settimana Sociale dei cattolici d'Italia (Firenze 22-28 ottobre 1945), Rome, 1946.

xxix The most eminent scholar of dossettismo, and Italian political Catholicism writ large, is Paolo Pombeni; see Paolo Pombeni, Il gruppo dossettiano e la fondarione della democrazia in Italia, 1943-1948, Bologna, 1979; idem, Le 'Cronache Sociali' di Dossetti: Geografia di un movimento d'opinione, Florence, 1976.

${ }^{x x x}$ A dense intellectual and existential biography is Paolo Pombeni, Giuseppe Dossetti: L'avventura politica di un riformatore cristiano, Bologna, 2013.

xxxi On 31 July 1945, Dossetti lauded the outcome of the English elections-in an article titled 'Triple Victory' and published by the newspaper Reggio Democratica-as the triumph of a 
'substantial' democracy opening the way to 'solidarity and equality'; the article is now in Giuseppe Dossetti, Scritti reggiani, 1944-1948 (Rome, 1982), p. 193.

xxxii In 1947 La Pira, analysing the 'Labour experiment', praised 'the British evolutionary drive which, in contrast to what often happens in continental Europe and elsewhere, hardly ever stops for long'; Giorgio La Pira, 'Le due fasi dell'esperimento laburista', Cronache Sociali, 15 November 1947, pp. 9-11: p. 9; the dossettiani sponsored the translation of Cripp's Feet on the Ground in 1950. On the influence of Keynes on the dossettiani see Pombeni, Il gruppo dossettiano, p. 378, pp. 380-81, and Eugenio Biagini, 'Keynesian Ideas and the Recasting of Italian Democracy', in Ewen H. H. Green and Duncan M. Tanner (eds), The Strange Survival of Liberal England: Political Leaders, Moral Values and the Reception of Economic Debate, Cambridge, UK, 2007, pp. 212-44: pp. 238-39

xxxiii Giorgio La Pira, 'L'attesa della povera gente', Cronache Sociali, 15 April 1950, pp. 2-6: pp. 3-4; idem, 'Difesa della povera gente', Conache Sociali, 1 July 1950, pp. 1-9.

xxxiv On Dossetti's youth see Enrico Galavotti, Il giovani Dossetti. Gli anni della formazione, 19131939, Bologna, 2006.

xxxv Enrico Galavotti Il professorino. Giuseppe Dossetti tra la crisi del fascismo e la costruzione della democrazia, 1940-1948, Bologna, 2013, p. 11. See also our review discussion of Galavotti in Journal of Modern Italian Studies, 20:3, 2015, pp. 408-10.

xxxvi For a lucid overview see Martin Conway, Catholic Politics in Europe, 1918-1945 (New York, 1997).

xxxvii This section is largely based on Müller, Contesting Democracy, pp. 134-38, and idem, 'Die eigentlich katholische Entscharfung? Jacques Maritain und die Fluchtwege aus dem Zeitalter der Extreme', Zeitscbrift für Ideengescbicbte 2:3, 2008, pp. 40-54. For Maritain's personal and intellectual 
biography see John Di Joseph, Jacques Maritain and the Moral Foundation of Democracy, Lanham, MD, 1996; Bernard Doering, Jacques Maritain and the French Catholic Intellectuals, Notre Dame, IND, 1983; Jean-Luc Barré, Jacques et Raïssa Maritain: les mendiants du Ciel: biographies croisées, Paris, 1995. xxxviii Samuel Moyn, 'The Secret History of Constitutional Dignity', Yale Human Rights and Development Journal, 17:1, 2014, pp. 39-73; idem, Christian Human Rights, Philadelphia, 2015, pp. 2564; James Chappel, 'The Catholic Origins of Totalitarianism Theory in Interwar Europe', Modern Intellectual History, 8:3, 2011, pp. 561-90.

xxxix What follows on Mounier is based on Jean Claude Delbreil, 'The French Catholic Left and the Political Parties', in Horn and Gerard, Left Catholicism, pp. 45-63 (esp. pp. 60-62, 'The Catholic Left, Catholic Progressivism, and Emmanuel Mounier'); John Hellman, Emmanuel Mounier and the New Catholic Left, 1930-1950, Toronto, 1981; Rufus W. Rauch Jr., Politics and Beliefs in Contemporary France: Emmanuel Mounier and Christian Democracy, 1932-1950, The Hague, 1972.

${ }^{x l}$ Quoted in Samuel Moyn, 'Personalism, Community and the Origins of Human Rights', in Stefan-Ludwig Hoffmann (ed.), Human Rights in the Twentieth Century (New York, 2011), pp. 86106: p. 89.

xli On this point see Toni Judt, Past Imperfect: French Intellectuals, 1944-1956, Berkeley, 1992, pp. 8690; John Hellman, The Knight-Monks of Vicky France: Uriage, 1940-1945, Montreal and Kingston, 1997. For a balanced assessment of 'personalism' see Paul Ricoeur, 'Une philosophie personnaliste', Esprit 18:174, 1950, pp. 860-87.

xlii Müller, Contesting Democracy, p. 137.

xliii Quoted in Sergio Belardinelli, 'Die politische Philosophie des christlichen Personalismus', in Karl Graf Ballestrem and Henning Ottmann (eds), Politische Philosopbie des 20. Jahrbunderts, Munich, 1990, pp. 243-62: p. 251. 
xliv Jacques Maritain, Christianity and Democracy, transl. Doris C. Anson, San Francisco, CA, 1943, p. 37.

xlv Jacques Maritain, 'Au sujet de la democratie et la revolution', L'Aube, 25 January 1934. On the controversy between Mounier and Archambault see Rauch Jr., Politics and Beliefs, pp. 113-25.

xlvi Historian Zeev Sternhell defined Mounier as a representative of those anti-democratic 'neither Right nor Left' ideologies of the 1930s, eventually leading to a form of Fascism; Zeev Sternhell, Ni droite, ni gauche. L'idéologie fasciste en France, Paris, 1983.

xlvii Emmanuel Mounier, 'Pour une technique des moyens spiritual' (November, 1934 and February, 1935), quoted in Rauch Jr., Politics and Beliefs, 77-78

xlviii Jan-Werner Müller, 'The Paradoxes of Post-War Italian Political Thought', History of European Ideas 39:1, 2013, pp. 79-102: pp. 85-7; Jean-Dominique Durand, 'Jacques Maritain et l'Italie', in Bernard Hubert (ed.), Jacques Maritain en Europe: la réception de sa pensée, Paris, 1996, pp. 13-85; Achille Ardigò, 'Jacques Maritain e "Cronache Sociali" (ovvero Maritain e il dossettismo)', in Giancarlo Galeazzi (ed.), Il pensiero politico di Jacques Maritain, Milan, 1978, pp. 195-202.

xlix Quoted in Paolo Pombeni, 'Anti-Liberalism and the Liberal Legacy in Post-war European Constitutionalism: Consideration on Some Case Studies', European Journal of Political Theory 7:1, 2008, pp. 31-44: p. 35.

${ }^{1}$ Giorgio La Pira, 'Il valore della Costituzione Italiana', Cronache Sociali, 31 January 1948, pp. 1-3.

li See Déclaration des droits des personnes et des communautés (1941), and Faut-il refaire la déclaration des droits? (1944), now in Emanuel Mounier, Oeuvres, vol. 4, Paris, 1963, pp. 96-104. 
lii On this see also Müller, 'The Paradoxes', p. 86; Carlo Masala, 'Born for Government: the Democrazia Cristiana in Italy', in Michael Gehler and Wolfram Kaiser (eds), Cbristian Democracy in Europe since 1945, London and New York, 2004, pp. 88-117: p. 90 and pp. 92-4.

liii On this see Pietro Scoppola, La Repubblica dei partiti. Evoluzione e crisi di un sistema politico, 1945 1996, Bologna, 1997, pp. 114-18; Gianni Baget Bozzo, Il partito cristiano al potere: La D.C di De Gasperi e Dossetti 1945-1954 (Florence, 1974).

liv Giuseppe Lazzatti, 'Azione Cattolica e Azione Politica', Cronache Sociali, 1-15 November 1948, pp. 1-3; In the words of another dossettiano, Christian Democracy was not a Catholic party and, as such, it must be independent from the Church and from the clergy; Amintore Fanfani, 'Partiti di ispirazione Cristiana e Chiesa cattolica', Humanitas 1:2, 1946, pp. 381-85; see also Alberto Melloni, Dossetti e l'indicibile: Il quaderno scomparso di 'Cronache Sociali': I cattolici per un nuovo partito a sinistra della Dc (1948), Rome, 2013.

lv In 1948-1949 Dossetti advocated a position of neutrality between the two blocks of the Cold War and repeatedly criticized the ratification of Atlantic Treaty, before voting it in the Parliament following party's discipline; see 'L'o.d.g. Dossetti al gruppo Dc sulla politica estera (1.12.1948)', in Giuseppe Dossetti, La ricerca costituente, 1945-1952, ed. Alberto Melloni, Bologna, 1994, p. 372; 'Giuseppe Dossetti, 'Unità della politica: connessione fra la politica interna e la politica estera italiana', Cronache Sociali, 31 December 1948, pp. 1-4; 'Dichiarazioni di Dossetti', Il Popolo, 9 March 1949. In a 1946 speech, Dossetti defined the USSR a 'more vital' society than the United States. Americans, he said, 'do not understand' European 'problems'; Russians were instead capable of an 'admirable and sensitive participation' in the European debate; the text is in Fondazione per le Scienze Religiose Giovanni XXIII, Fondo Cronache Sociali, E, 1, 2. 
lvi Having retired from public life nearly 40 years earlier, Dossetti shortly reappeared in public in 1994, when he expressed publicly his worries for the proposed modifications of the Constitution under way with the new Berlusconi government. Dossetti died in 1996.

lvii On this see also Luciano Canfora, Democracy in Europe: A History of an Ideology, transl. Simon Jones, Malden, Mass., pp. 182-84.

lviii See the meeting of the first sub-committee of the Constituent Assembly (9 September 1946) and, in particular, the contributions of Dossetti and Togliatti; Atti dell'Assemblea Costituente. Prima sottocommissione. Resoconti Sommari (Rome, 1946), pp. 21-2.

lix Atti, p. 171.

1x Atti, p. 165. On the same occasion, Togliatti said: 'our democratic regime differs from the previous century's individualist liberal regime ... The Christian Democrats will give this principle [liberty] one expression, the social-communists another; but a point of convergence may be reached, namely the reading that for us liberty is to be guaranteed by the State in order for certain aims to be achieved: perfecting the human person; strengthening and developing the democratic regime; constantly increasing social solidarity; three objectives we declare we entertain (Atti, p. 167).

lxi See the debate at the first subcommittee for the preparatory text of the Constitution in Atti, pp. 447-54.

lxii The opposite conclusion was reached in a country facing many of the same debates, and where Catholics likewise sought to give their imprint: in the Constitution of the German Federal Republic there is an article (20) that unequivocally legalizes the right of resistance, stating that 
'against anyone who attempts to abolish that order [the democratic Constitution], all Germans have a right of resistance, if no other remedies are possible'.

lxiii Paolo Pombeni, 'Individuo/persona nella Costituzione Italiana. Il contributo del Dossettismo', Parola Chiave 10-11, 1996, pp. 197-218.

lxiv Rosario Forlenza, 'On Christian Democracy: From the Abendland to the Origins of the European Union', Contemporary European History, forthcoming.

Ixv Müller, 'The Paradoxes', pp-84-9; idem, Contesting Democracy, pp. 133-43; Pombeni, 'AntiLiberalism and the Liberal Legacy'. See also the review discussion of Pombeni's book on Dossetti (quoted in endnoted 30 above) by Forlenza in Journal of Modern Italian Studies, 19:4, 2014, pp. $486-88$.

Ixvi 'Christian Democracy does not want to nor can it be a conservative movement, but one imbued with the certainty that between the ideology and experience of capitalistic Liberalism and the experience, if not the ideology, of massive anti-Capitalist movements, the most radically antiChristian is not the latter, but the former, therefore Christians, hitherto firm and fervent critics and opponents of every socialist revolutionary position (because materialist, atheist, and violent), must likewise become as never before firm and fervent critics and opponents of any reactionary position, that under the veneer of legality and justice may cover violent illegality and injustice no less grave, albeit better concealed, than any committed by the desperate and the marginalized'; Giuseppe Dossetti, 'Il Movimento Democratico Cristiano (27 March 1945)', in Scritti politici, 1943-1951, ed. Giuseppe Trotta, Genova, 1995, pp. 20-1 (italics added).

lxvii Müller, 'The Paradoxes', p. 89; here, as elsewhere, Muller's analysis rests on his reading of Pombeni, 'The Ideology of Christian Democracy', p. 291. 